\title{
The effect of cytokinins on shoot proliferation, biochemical changes and genetic stability of Rhododendron 'Kazimierz Odnowiciel' in the in vitro cultures
}

\author{
Karolina Nowakowska ${ }^{1}$ [D Anna Pińkowska ${ }^{2}$. Ewa Siedlecka ${ }^{3} \cdot$ Andrzej Pacholczak $^{1}$
}

Received: 20 August 2021 / Accepted: 23 November 2021 / Published online: 4 December 2021

(C) The Author(s) 2021

\begin{abstract}
Shoot proliferation is a very important micropropagation phase, decisive for economic efficiency of this method for a given taxon. To obtain a high multiplication ratio and a good quality of microshoots a detailed propagation protocol must be developed for particular species or even cultivars. Rhododendron 'Kazimierz Odnowiciel' is a relatively new cultivar distinguished by large, beautiful flowers and high frost resistance so there is a need to develop an efficient method of its propagation to satisfy a growing demand for this plant. The aim of the experiment was to evaluate effects of cytokinins: meta-Topolin $(\mathrm{mT})$, zeatin (ZEA), 6-benzyladenine (BA), thidiazuron (TDZ), 2-isopentenyladenine (2iP), or the combination of 2iP+ZEA on proliferation of shoots in $R$. 'Kazimierz Odnowiciel' cultured on Anderson's medium (AN). Biochemical changes in plant material affected by cytokinins during this phase of micropropagation were determined and occurrence of genetical changes was followed using ISSR markers. TDZ, ZEA or the combination of ZEA+2iP resulted in 100\% explant regeneration. On the medium with TDZ or ZEA over two new shoots per explant were produced but the highest proliferation was attained on the medium containing ZEA $+2 \mathrm{iP}$ - over three shoots per explant. Microshoots developed in this treatment had also the highest contents of chlorophyll, carotenoids and soluble sugars as well as the highest catalase activity. Microshoots formed on the medium with zeatin showed the lowest polymorphism (below 4\%) relative to a stock plant.
\end{abstract}

\section{Key message}

ZEA and 2iP increased chlorophyll, carotenoids and total soluble sugar contents in micropropagated shoots and strengthened plant defense against oxidative stress in tissue culture.

Keywords Micropropagation · Organic compounds $\cdot$ Hydrogen peroxide $\cdot$ Catalase $\cdot$ ISSR markers $\cdot$ Somaclonal variation

Communicated by T. Winkelmann.

This article belongs to the Topical Collection: Biotechnology of Ornamental Plants.

Karolina Nowakowska

karolina_nowakowska@sggw.edu.pl

1 Section of Ornamental Plants, Institute of Horticultural Sciences, Warsaw University of Life Sciences (SGGW), 166 Nowoursynowska Str, 02-787 Warszawa, Poland

2 Department of Plant Protection, Section of Applied Entomology, Institute of Horticultural Sciences, Warsaw University of Life Sciences (SGGW), 159 Nowoursynowska Str, 02-787 Warszawa, Poland

3 Department of Plant Genetics, Breeding and Biotechnology, Institute of Biology, Warsaw University of Life Sciences (SGGW), 159 Nowoursynowska Str, 02-787 Warszawa, Poland

\begin{tabular}{ll}
\multicolumn{2}{l}{ Abbreviations } \\
2iP & 2-isopentenyladenine \\
AN & Anderson medium (1984) \\
BA & 6-benzyladenine \\
CAT & catalase \\
ISSR & inter simple sequence repeat (marker) \\
MS & Murashige and Skoog (1962) medium \\
mT & meta-Topolin \\
NAA & 1-naphthalene acetic acid \\
PGR & plant growth regulator \\
POD & peroxidase \\
ROS & reactive oxygen species \\
TDZ & thidiazuron \\
WPM & woody plant medium (1980) \\
ZEA & zeatin
\end{tabular}

\section{Abbreviations}

Anderson medium (1984)

nine

inter simple sequence repeat (marker)

MS Murashige and Skoog (1962) medium

mT meta-Topolin

PGR plant growth regulator

POD peroxidase

ROS reactive oxygen species

WPM woody plant medium (1980)

ZEA zeatin 


\section{Introduction}

Rhododendrons - next to roses - are considered as the most beautiful ornamental shrubs. It was Parkinson who first introduced them into gardens in 1629. They are prized by abundant flowering, variety of flower colors and shapes, evergreen foliage and diversified plant forms - starting from subshrubs to trees several meters high (Czekalski 1983). Rhododendron 'Kazimierz Odnowiciel' is a hardy hybrid bred by crossing $R$. 'Rasputin' with the Finish cultivar $R$. 'Helsinki University'. It belongs to the Polish series of 'Royal Rhododendrons' characterized by high resistance to low temperatures (even to $-30{ }^{\circ} \mathrm{C}$ ). The crossing resulted in a shrub of the erect habit and quick, vigorous growth what allows to compare it to $R$. 'Catawbiense Grandiflorum', with similar ornamental values, including large, bi-colored flowers. After 10 years $R$. 'Kazimierz Odnowiciel' may attain 2.2 m (Jílek 2012). Micropropagation is one of the main methods of vegetative propagation in numerous valuable ornamentals. It is used for a mass production of genetically identical, physiologically uniform and properly growing plantlets which can be produced in a short time irrespective of atmospheric conditions (Rathore et al. 2005; Rout et al. 2006; Hussain et al. 2012). Though nowadays multiplication of herbaceous plants has become less problematic woody plants remain often a major challenge. Their micropropagation is possible, however, for many taxa the propagation procedures are imperfect or unproven thus they do not allow to obtain the planned effects. A factor which significantly affects micropropagation of woody plants is maturity of stock plants when explants are collected. The older the stock plants the more frequent are the adverse features such as slowed down growth, limited or completely lost rooting ability and sometimes plagiotropia (Pierik 1990; Rathore et al. 2005). What more, propagation of woody plants is more difficult as they are submitted to seasonal and environmental stresses which affect explant behaviour during culture (Rathore et al. 2005) which thus becomes more difficult to stabilize and multiply. Here plant growth regulators added to a culture medium can help to overcome the problems, especially cytokinins.

Plant growth regulators significantly affect morphogenesis in vitro. Induction of a given developmental path and regeneration of a respective organ result from a ratio between concentrations of exogenous and endogenous hormones (Santner et al. 2009; Rademacher 2015). The cytokinins have been known as plant growth regulators since 1950 when their ability to stimulate cell divisions was discovered. Later their ability to act together with other hormones in control of biochemical, physiological and morphogenetical processes in plants was described
(Gaspar et al. 1996; Nowakowska et al. 2019; Hallmark and Rashotte 2019). Cytokinins increase photosynthetically active pigments and are effective in delaying chlorophyll degradation (Hönig et al. 2018). By supporting the photosynthetic apparatus of plants, they also increase the content of total sugars in regenerating shoots on media with their addition (Pacholczak and Nowakowska 2019). Cytokinins actively defend plants against oxidative stress by stimulating activity of antioxidative enzymes (Souza et al. 2019; Nowakowska and Pacholczak 2020). Catalase (CAT) and peroxidase (POD) are among the most important elements of the plant antioxidative defense system. Catalase decomposes hydrogen peroxidea reactive oxygen species (ROS) associated with oxidative stress-to oxygen and hydrogen without participation of any additional reductants and is present mainly in peroxisomes but also in mitochondria and chloroplasts. Peroxidase decomposes $\mathrm{H}_{2} \mathrm{O}_{2}$ with the involvement of such reducing agents as glutathione (glutathione peroxidase) or ascorbate (ascorbate peroxidase) (Bian and Jiang 2009; Şen 2012).

Unfortunately, in spite of the correctly set culture conditions, including a type and concentration of PGRs, different variations occur in the multiplied material, especially those on genetic and epigenetic level (Rodríguez et al. 2012; Saha et al. 2016; Amin et al. 2018). The common is so called somaclonal variation described by Larkin and Scowcroft (Larkin and Scowcroft 1981) which consists in genetic changes in somatic cells which are vegetatively propagated. DNA markers allow to evaluate genetic variation of material used for breeding, to identify cultivars, to choose right specimens for crossing, to confirm a hybrid origin of the obtained progeny, as well as to identify and select desired plant forms (Podwyszynska et al. 2010; Bhattacharyya et al. 2017).

The aim of the experiment was to evaluate the effects of several cytokinins on shoot proliferation in the in vitro culture of the new Rhododendron hybrid 'Kazimierz Odnowiciel'. Their effects on biochemical changes in microshoots, the elements of the antioxidant defense system and genetic stability were also determined.

\section{Materials and methods}

\section{Influence of cytokinins on shoot multiplication}

Apical shoot segments (min. $0.8-1 \mathrm{~cm}$ long), regenerated on the Anderson medium (AN) (Anderson 1984) with $1 \mathrm{mg} \cdot \mathrm{l}^{-1}$ $2 \mathrm{iP}+1 \mathrm{mg} \cdot \mathrm{l}^{-1} \mathrm{ZEA}$, were taken from an established sixweek in vitro culture, cut into one- or two-node explants (depending on the length of internodes) and were placed onto the medium. For the multiplication phase the AN medium was enriched with $1 \mathrm{mg} \cdot 1^{-1}$ : meta-Topolin (mT), zeatin (ZEA), 6-benzyladenine (BA), thidiazuron (TDZ), 
Table 1 List of ISSR markers used for genetic analysis of Rhododendron 'K. Odnowiciel' microcuttings, annealing temperatures and the obtained polymorphic products

\begin{tabular}{lllll}
\hline Marker & Sequence $\left(5^{\prime}-3^{\prime}\right)$ & $\begin{array}{l}\text { Annealing tem- } \\
\text { perature }\left({ }^{\circ} \mathrm{C}\right)\end{array}$ & $\begin{array}{l}\text { Number of bands } \\
\text { scored per plant }\end{array}$ & $\begin{array}{l}\text { Polymorphic } \\
\text { bands per plant }\end{array}$ \\
\hline UBC 808 & AGAGAGAGAGAGAGAGC & 48.0 & 4 & 0 \\
UBC 811 & GAGAGAGAGAGAGAGAC & 49.0 & 10 & 4 \\
UBC 812 & GAGAGAGAGAGAGAGAA & 45.0 & 3 & 1 \\
UBC 818 & CACACACACACACACAG & 48.0 & 8 & 3 \\
UBC 825 & ACACACACACACACACT & 45.0 & 5 & 1 \\
UBC 835 & AGAGAGAGAGAGAGAGGC & 51.0 & 6 & 1 \\
UBC 836 & AGAGAGAGAGAGAGAGCA & 51.0 & 5 & 1 \\
UBC 840 & GAGAGAGAGAGAGAGACT & 51.0 & 8 & 2 \\
UBC 841 & GAGAGAGAGAGAGAGATC & 51.0 & 10 & 3 \\
UBC 842 & GAGAGAGAGAGAGAGACG & 52.0 & 6 & 0 \\
UBC 848 & CACACACACACACACAGG & 51.0 & 3 & 0 \\
UBC 876 & GATAGATAGACAGACA & 40.0 & 2 & 0 \\
UBC 888 & GGGCACACACACACACA & 50.0 & 12 & 0 \\
Total & & & 82 & 16 \\
Average number & per primer & 6.3 & 1.23 \\
\hline
\end{tabular}

2-isopentenyladenine (2iP), or $1 \mathrm{mg} \cdot \mathrm{l}^{-1} 2 \mathrm{iP}+1 \mathrm{mg} \cdot \mathrm{l}^{-1} \mathrm{ZEA}$ (all growth regulators from Duchefa, Germany). These concentrations were chosen after preliminary experiments. The control treatment was the AN PGRs-free medium. Sucrose $\left(10 \mathrm{~g} \cdot \mathrm{l}^{-1}\right)$ with glucose $\left(5 \mathrm{~g} \cdot \mathrm{l}^{-1}\right)$ served as the carbon source in the medium. The medium was solidified with $5.5 \mathrm{~g} \mathrm{l}^{-1}$ Gelrite and its $\mathrm{pH}$ was adjusted to 5.4 before autoclaving. The $250 \mathrm{ml}$ jars filled with $50 \mathrm{ml}$ of the medium were closed with transparent plastic covers and autoclaved for $20 \mathrm{~min}$ at $121^{\circ} \mathrm{C}$ and $110 \mathrm{kPa}$.

During the multiplication phase, the jars with explants were kept in a growth chamber with $23 \pm 1^{\circ} \mathrm{C}, 16 \mathrm{~h}$ day with light at $35 \mu \mathrm{mol} \mathrm{m}{ }^{-2} \mathrm{~s}^{-1}$ photosynthetic photon flux density, provided by fluorescent lamps. Every treatment consisted of 12 replicates, each containing 5 explants. The percentage of regenerated plants, shoot lengths, and mean shoot numbers were evaluated after 6 weeks.

\section{Biochemical analyses}

From six-week-old axillary shoots, $0.25 \mathrm{~g}$ weights were prepared for analyses of organic compounds and antioxidant enzyme activities. Triplicate extracts were prepared for each analysis and three measurements were done for each extract producing nine readings for each data point. The total chlorophyll and carotenoids content was analyzed according to Lichtenthaler and Wellburn (1983). Total soluble sugars were measured by the colorimetric method of Dubois et al. (1956). Hydrogen peroxide was measured according to Pick and Keisari (1980), the catalase activity according to Goth (1991) and the peroxidase activity by the method of Toczko and Grzelińska (2001). Absorbance was measured with the spectrophotometer UV-1601 PC (Schimadzu).

\section{Statistical analysis}

Arcsine transformation was performed for all experimental data taken in percentages before subjecting them to statistical analysis (Compton 1994). All experimental data (mean number of shoots and shoot length, as well as results of the biochemical analyses) were subjected to a one-way factorial ANOVA followed by the Tukey multiple range test at $\alpha=0.05$ (Wójcik and Laudański 1989).

\section{Assessment of genetic stability of microcuttings using ISSR markers}

The aim of the analysis was to evaluate the influence of selected cytokinins on the genetic stability of the obtained $R$. 'Kazimierz Odnowiciel' microcuttings. Six week old microshoots (like in biochemical analysis) from 12 randomly selected microshoots from each treatment were collected and $100 \mathrm{mg}$ of the tissue were ground in liquid nitrogen and stored at $-80{ }^{\circ} \mathrm{C}$. In addition, before the initiation of the cultures, material was also collected from the mother shrub which were young tops of shoots. 29 microsatellite primers (UBC, University of British Columbia, Canada) were randomly selected and tested $(807,808,809,810$, $811,812,816,818,819,825,835,836,840,841,842,847$, $848,856,857,861,872,873,876,878,884,888,890,899$, $900)$. Thirteen of them (Table 1) produced highly readable and reproducible bands and were selected for the analysis. Genomic DNA was extracted using the GeneMATRIX ${ }^{\mathrm{TM}}$ Plant and Fungi DNA Purification Kit (EURX®, Poland). The polymerase chain reaction was performed with $25 \mu \mathrm{l}$ of the mixture consisting of: $1 \mu \mathrm{l}$ of DNA, $0.125 \mu \mathrm{l}$ Taq DNA Polymerase (EURX®, Poland), $2 \mu$ l of ISSR primer, $2.5 \mu \mathrm{l}$ 
of dNTPS (EURX®, Poland), $16.875 \mu \mathrm{l}$ of autoclaved water, and $2.5 \mu \mathrm{l}$ of buffer (x10 Taq buffer with $\mathrm{KCl}$, EURX®, Poland).

The initial denaturation was 4 min at $94^{\circ} \mathrm{C}$, followed by 38 cycles of 1 min denaturation at $94^{\circ} \mathrm{C}, 1$ min annealing at the temperature shown in Tables 1 , and 2 min extension at $72^{\circ} \mathrm{C}$, with a final extension at $72^{\circ} \mathrm{C}$ for $2 \mathrm{~min}$. Samples were stored at $4^{\circ} \mathrm{C}$. ISSR amplifications were performed at least three times and only the reproducible PCR products were scored. Amplification products for all samples were resolved on $1.5 \%(\mathrm{w} / \mathrm{v})$ agarose basic LE (Prona ${ }^{\circledR}, \mathrm{ABO} \mathrm{Sp}$. $\mathrm{z}$ o.o, Poland) gels in 1xTAE buffer and stained with $10 \mu \mathrm{l}$ ethidium bromide (Sigma-Aldrich ${ }^{\circledR}$ ). Images were recorded using a gel documentation system (Syngen Imagine $®)$. The size of each amplicon was estimated by comparing it with the GeneRuler 100 bp Plus DNA ladder (Thermo Scientific ${ }^{\circledR}$, USA).

\section{Molecular data analysis}

The data were pooled into a binary matrix based on the presence (1) or absence (0) of the selected bands. Differences in band intensity were ignored. Genetic similarity was estimated using the Jaccard's coefficient (Jaccard 1908). These were used to construct a dendrogram through the XLSTAT 2018.6 program software (Microsoft Excel ${ }^{\circledR}$ ) using unweighted pair-group method with arithmetic mean (UPGMA) method.

\section{Results}

\section{Influence of cytokinins on shoot multiplication}

Supplementing the AN medium with any of the cytokinin under study was statistically significant and positive (Table 2) as - relative to the control devoid of cytokinins the percentage of regenerated explants increased in all but one $(\mathrm{mT})$ treatment. Presence in the medium of thidiazuron, zeatin and the combination of zeatin with 2-isopentenyladenine resulted in $100 \%$ regeneration of explants. The highest regeneration ratio i.e. a number of axillary shoots produced by an explant was obtained in presence of two cytokinins used jointly - 2iP plus ZEA - where over 3 shoots appeared. Over two shoots were regenerated on the medium supplemented with TDZ or ZEA. Other growth regulators did not increase shoot number relative to the control treatment without cytokinins (Table 2; Fig. 1). Also shoot length was significantly increased by all the cytokinins. It was doubled as compared to the control in the treatment with zeatin or its combination with $2 \mathrm{iP}$ (Table 2).
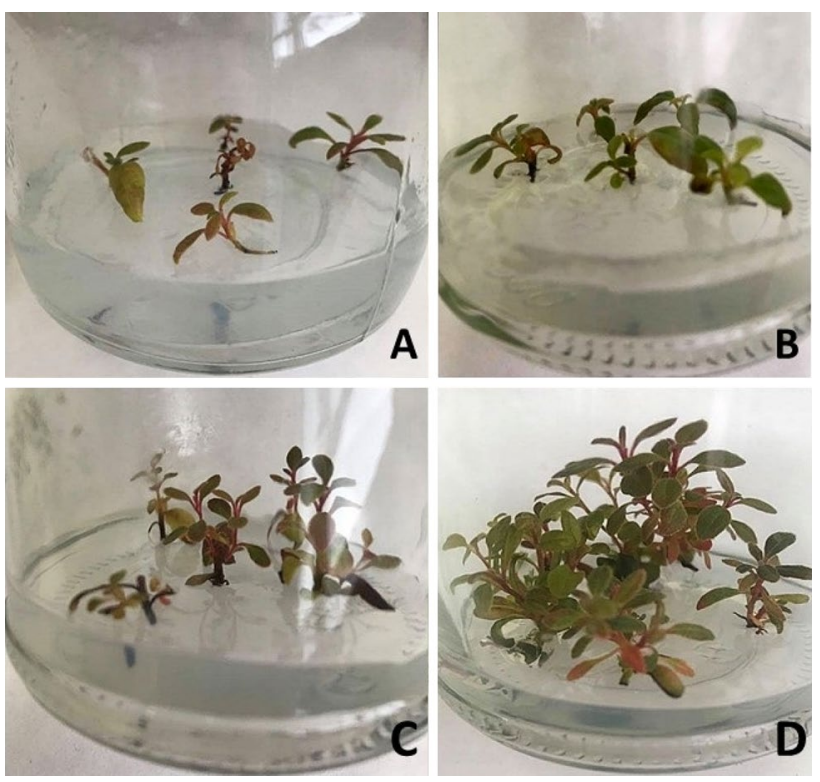

Fig. 1 Rhododendron 'Kazimierz Odnowiciel' microshoots proliferation on AN medium with: A - PGRs-free medium ("0" control), B $1 \mathrm{mg} \mathrm{L}^{-1} \mathrm{mT}, \mathbf{C}-1 \mathrm{mg} \mathrm{L}^{-1} 2 \mathrm{iP}, \mathbf{D}-1 \mathrm{mg} \mathrm{L}^{-1} 2 \mathrm{iP}+1 \mathrm{mg} \mathrm{L}^{-1} \mathrm{ZEA} ; 6$ weeks after starting the experiment

\section{Biochemical analysis}

Supplementing the culture medium with cytokinins resulted in the increases in contents of chlorophyll, total soluble sugars and hydrogen peroxide as well as of enhanced activity of catalase and decease that of peroxidase determined in regenerated Rhododendron shoots (Table 3).

In shoots regenerated in presence of $\mathrm{mT}$ and TDZ the chlorophyll content increased by ca. $18 \%$ relative to the control while addition of ZEA and 2iP resulted in $22-25 \%$ increase. The highest chlorophyll level was found in shoots regenerated on medium with benzyladenine and due to the joint application of ZEA and 2iP where 29 and 34\% more chlorophyll was determined than in the control treatment, respectively. Also carotenoids increased in shoots from the cytokinin-enriched cultures: by 13 and $14 \%$ in presence of zeatin and benzyladenine, respectively and by 22 and $23 \%$ due to $2 \mathrm{iP}$ or the combination of $2 \mathrm{iP}$ with zeatin, respectively (Table 3 ).

Contents of total soluble sugars increased by $32-37 \%$ in shoots regenerated in presence of $\mathrm{mT}$, ZEA TDZ or $2 \mathrm{iP}$ while the joint application of ZEA and $2 \mathrm{iP}$ resulted in the highest soluble sugar increase, i.e. nearly $50 \%$ relative to the control (Table 3).

In presence of cytokinins the contents of hydrogen peroxide increased in regenerated shoots. More $\mathrm{H}_{2} \mathrm{O}_{2}$, by nearly $30 \%$, had shoots regenerating on medium with $\mathrm{mT}$ or with ZEA, compared to the control combination. Its highest levels were determined in shoots regenerated in presence of TDZ 
Table 2 Effect of cytokinins on the axillary shoot formation

\begin{tabular}{lcll}
\hline $\begin{array}{l}\text { Parameter AN medium with } \\
\text { cytokinins }\left[\mathrm{mg} \mathrm{L}^{-1}\right]\end{array}$ & Regenerated explants $(\%)$ & Number of shoots & Shoot length $(\mathrm{cm})$ \\
\hline cytokinin-free AN & $85.0 \pm 14.1 \mathrm{a}$ & $0.9 \pm 0.2 \mathrm{a}$ & $0.6 \pm 0.1 \mathrm{a}$ \\
$1 \mathrm{mT}$ & $94.1 \pm 9.7 \mathrm{ab}$ & $1.2 \pm 0.3 \mathrm{a}$ & $0.9 \pm 0.2 \mathrm{~b}$ \\
$1 \mathrm{ZEA}$ & $100.0 \pm 0.0 \mathrm{~b}$ & $2.4 \pm 0.6 \mathrm{~b}$ & $1.2 \pm 0.4 \mathrm{c}$ \\
$1 \mathrm{BA}$ & $96.1 \pm 8.4 \mathrm{~b}$ & $1.3 \pm 0.4 \mathrm{a}$ & $0.9 \pm 0.3 \mathrm{~b}$ \\
$1 \mathrm{TDZ}$ & $100.0 \pm 0.0 \mathrm{~b}$ & $2.6 \pm 0.8 \mathrm{~b}$ & $0.9 \pm 0.1 \mathrm{~b}$ \\
$12 \mathrm{iP}$ & $96.1 \pm 8.4 \mathrm{~b}$ & $1.5 \pm 0.3 \mathrm{a}$ & $1.0 \pm 0.2 \mathrm{~b}$ \\
$12 \mathrm{iP}+1 \mathrm{ZEA}$ & $100.0 \pm 0.0 \mathrm{~b}$ & $3.1 \pm 1.0 \mathrm{c}$ & $1.3 \pm 0.3 \mathrm{c}$ \\
\hline
\end{tabular}

*Means \pm standard deviation within a column followed by the same letter are not significantly different according to Tukey's multiple range test at $\alpha=0.05$

Table 3 Effect of cytokinins on contents of chlorophyll, carotenoids, total soluble sugar and hydrogen peroxide $\left(\mathrm{H}_{2} \mathrm{O}_{2}\right)$, and on activity of catalase and peroxidase in regenerated shoots

\begin{tabular}{|c|c|c|c|c|c|c|}
\hline $\begin{array}{l}\text { Parameter AN } \\
\text { medium with cyto- } \\
\text { kinins }\left[\mathrm{mg} \mathrm{L}^{-1}\right]\end{array}$ & $\begin{array}{l}\text { Chlorophyll } \\
(\mathrm{a}+\mathrm{b})\left(\mathrm{mg} \cdot \mathrm{g}^{-1}\right. \\
\text { DW) }\end{array}$ & $\begin{array}{l}\text { Carotenoids }\left(\mathrm{mg} \cdot \mathrm{g}^{-1}\right. \\
\text { DW) }\end{array}$ & $\begin{array}{l}\text { Total soluble } \\
\text { sugars }\left(\mathrm{mg} \cdot \mathrm{g}^{-1}\right. \\
\text { DW) }\end{array}$ & $\begin{array}{l}\text { Hydrogen peroxide } \\
\left(\mathrm{H}_{2} \mathrm{O}_{2}\right)\left(\mu \mathrm{g} \mathrm{g}^{-1}\right. \\
\text { DW })\end{array}$ & $\begin{array}{l}\text { Catalase activity } \\
\left.\text { (nkat } g^{-1} \mathrm{DW}\right)\end{array}$ & $\begin{array}{l}\text { Peroxidase activ- } \\
\left.\text { ity (nkat } g^{-1} \mathrm{DW}\right)\end{array}$ \\
\hline cytokinin-free AN & $4.4 \pm 0.2 \mathrm{a}^{*}$ & $0.98 \pm 0.02 \mathrm{a}$ & $105.8 \pm 3.5 \mathrm{a}$ & $124.0 \pm 16.9 \mathrm{a}$ & $400.3 \pm 118.7 \mathrm{a}$ & $0.56 \pm 0.02 \mathrm{e}$ \\
\hline $1 \mathrm{mT}$ & $5.2 \pm 0.2 b$ & $1.06 \pm 0.03 b$ & $144.1 \pm 9.6 \mathrm{c}$ & $159.5 \pm 6.8 \mathrm{bc}$ & $879.6 \pm 141.1 \mathrm{~b}$ & $0.29 \pm 0.05 \mathrm{~d}$ \\
\hline $1 \mathrm{ZEA}$ & $5.5 \pm 0.1 \mathrm{~cd}$ & $1.11 \pm 0.01 \mathrm{bc}$ & $140.1 \pm 5.7 \mathrm{c}$ & $160.1 \pm 5.9 \mathrm{bc}$ & $926.9 \pm 53.1 \mathrm{bc}$ & $0.21 \pm 0.02 \mathrm{c}$ \\
\hline $1 \mathrm{BA}$ & $5.7 \pm 0.1 \mathrm{de}$ & $1.12 \pm 0.04 \mathrm{c}$ & $120.9 \pm 5.1 b$ & $154.7 \pm 6.8 \mathrm{bc}$ & $1001.9 \pm 79.3 \mathrm{bc}$ & $0.19 \pm 0.0 \mathrm{bc}$ \\
\hline $1 \mathrm{TDZ}$ & $5.2 \pm 0.2 b$ & $1.07 \pm 0.05 b$ & $140.1 \pm 5.7 \mathrm{c}$ & $169.9 \pm 10.1 \mathrm{c}$ & $751.6 \pm 135.2 \mathrm{ab}$ & $0.14 \pm 0.0 \mathrm{ab}$ \\
\hline $12 \mathrm{iP}$ & $5.4 \pm 0.2 \mathrm{c}$ & $1.20 \pm 0.02 \mathrm{~d}$ & $145.3 \pm 9.7 \mathrm{c}$ & $144.1 \pm 9.6 \mathrm{~b}$ & $1328.9 \pm 148.2 \mathrm{~cd}$ & $0.22 \pm 0.03 \mathrm{c}$ \\
\hline $12 \mathrm{iP}+1 \mathrm{ZEA}$ & $5.9 \pm 0.1 \mathrm{e}$ & $1.21 \pm 0.01 \mathrm{~d}$ & $159.5 \pm 6.8 \mathrm{~d}$ & $168.7 \pm 11.9 \mathrm{c}$ & $1434.1 \pm 189.2 \mathrm{~d}$ & $0.13 \pm 0.02 \mathrm{a}$ \\
\hline
\end{tabular}

* Means \pm standard deviation within a column followed by the same letter are not significantly different according to Tukey's multiple range test at $\alpha=0.05$

or the combination of $\mathrm{ZEA}$ and $2 \mathrm{iP}-\mathrm{ca} .36 \%$ relative to the medium without cytokinin.

Catalase activity increased due to presence of all the cytokinins under study (Table 3).

It was doubled in shoots regenerated on the medium with ZEA or BA and tripled when $2 \mathrm{iP}$ or $2 \mathrm{iP}$ plus ZEA were present in the medium. Peroxidase activity was decreasing in shoots developed in presence of cytokinins. Twofold decrease occurred due to meta-Topolin application, while 2.5 times lower activity was recorded in treatment with ZEA, BA and $2 \mathrm{iP}$. The lowest enzyme activity was in shoots regenerated on the medium with TDZ or with the combination of 2iP plus ZEA - four times lower than in the control (Table 3).

\section{Assessment of genetic stability of microcuttings using ISSR markers}

The 13 ISSR markers used produced a total of 16 polymorphic products ( $18.8 \%$ of all products). On average, a single ISSR marker generated 6.3 bands, ranging in length from ca. 200-1500 bp (Table 1; Fig. 2). Five ISSR primers gave $100 \%$ monomorphic products (UBC 808, UBC 842, UBC
848, UBC 876, UBC 888) while the remaining markers produced polymorphic bands (Table 1; Fig. 2). For ISSR markers the mean value of similarity coefficients according to Jaccard stands at 0.896 (practically $90 \%$ similarity). The lower limit of the Jaccard's similarity coefficient value started with 0.843 (i.e. $84 \%$ similarity). The highest level of genetic similarity with mother plant (M), was in material from AN medium with ZEA (Fig. 3) which was identical to the mother shrub in over $96 \%$. Also microcuttings from medium with mT were genetically closer with mother plant (93\% similarity) than microshoots regenerated on media with other cytokinins or without them. The most genetically distant group were shoots regenerated on media with TDZ and BA (Fig. 3).

\section{Discussion}

Most of Rhododendron cultivars need specific conditions when cultured in vitro, i.e. an appropriate culture medium and an application of proper plant growth regulators. The following media have been reported as suitable for Rhododendron micropropagation: Anderson's (AN) (Anderson 


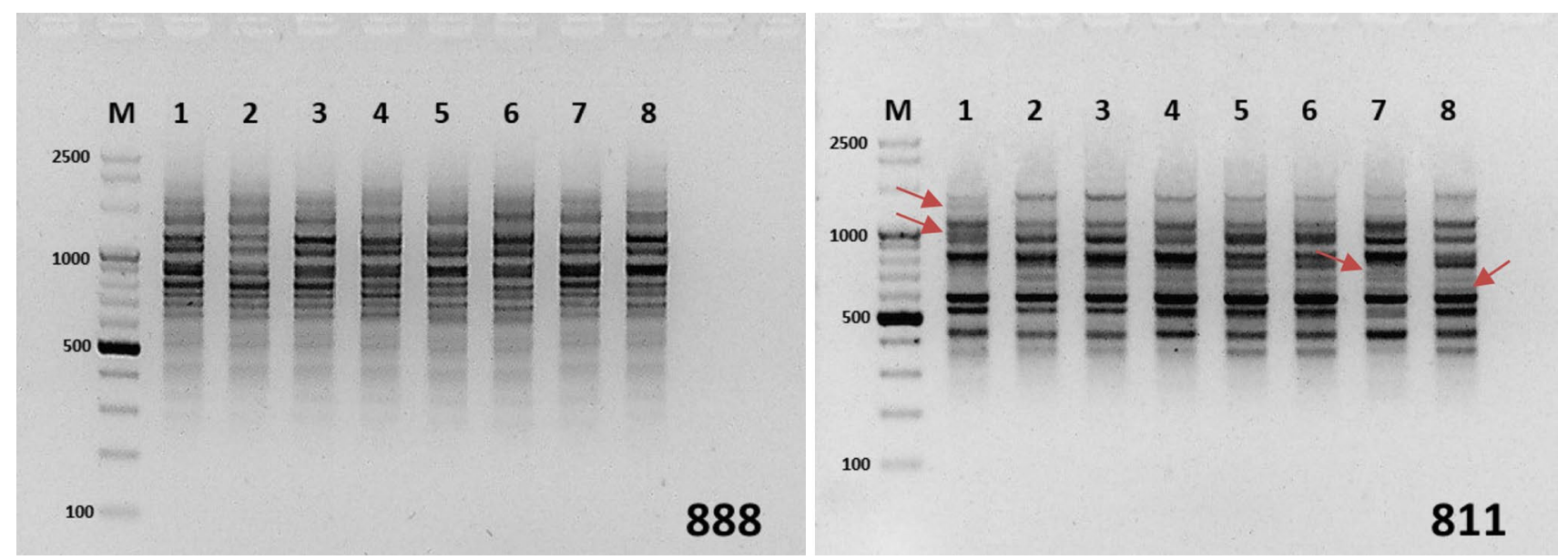

Fig. 2 ISSR (using primers 888 and 811) profiles of microcuttings of Rhododendron 'Kazimierz Odnowiciel' M-ladder, 1-“ 0 " without cytokinins, 2-medium with $1 \mathrm{mg} \mathrm{L}^{-1} \mathrm{mT}$, 3-medium with $1 \mathrm{mg} \mathrm{L}^{-1}$ ZEA, 4-medium with $1 \mathrm{mg} \mathrm{L}^{-1} \mathrm{BA}, 5$-medium with $1 \mathrm{mg} \mathrm{L}^{-1}$
TDZ, 6-medium with $1 \mathrm{mg} \mathrm{L}^{-1} 2 \mathrm{iP}, 7$-medium with $1 \mathrm{mg} \mathrm{L}^{-1}$ $2 \mathrm{iP}+1 \mathrm{mg} \mathrm{L}^{-1} \mathrm{ZEA}, 8$ - mother shrub; the red arrows indicate polymorphic bands
Fig. 3 UPGMA dendrogram of ISSR primers analysis showing genetic relationship among mother plant (M) and randomly selected Rhododendron 'Kazimierz Odnowiciel' microcuttings regenerating on the AN medium with the addition of selected cytokinins or without (0); dashed line: value of Jaccard's coefficient

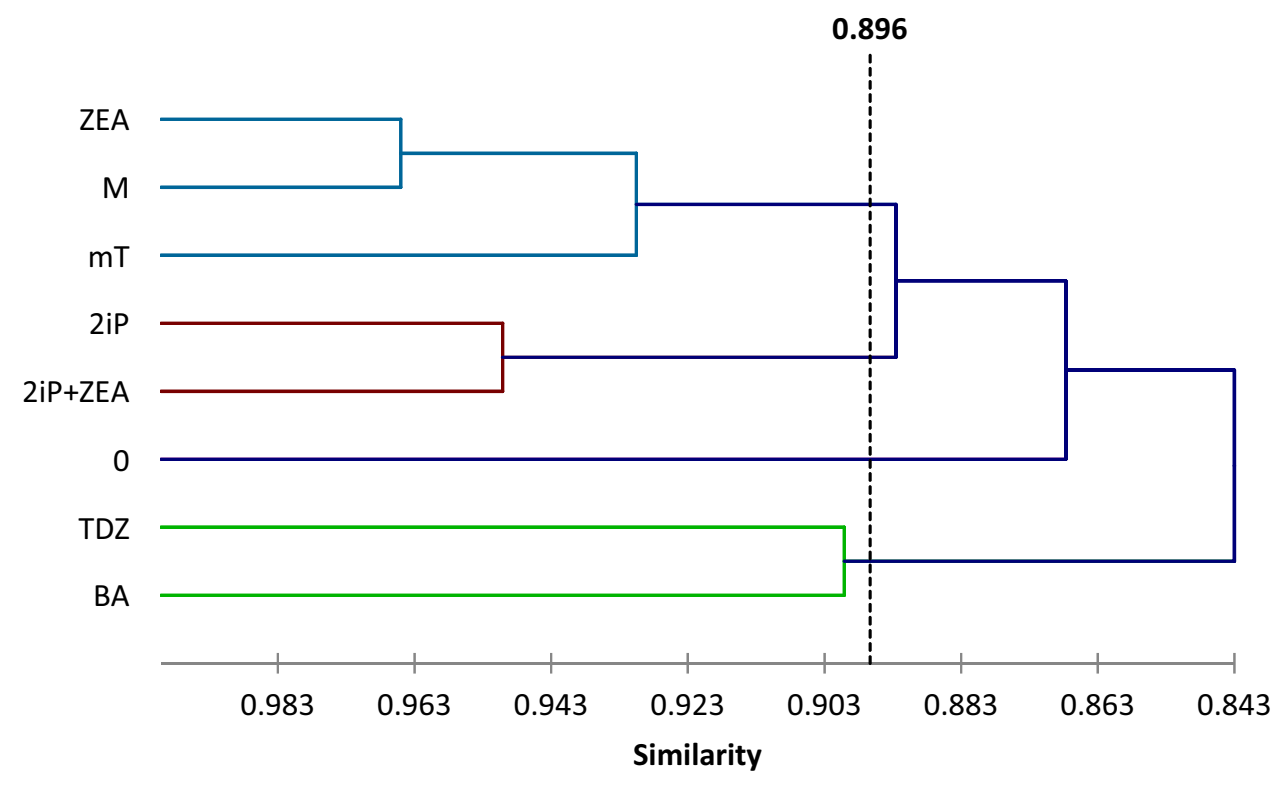

1984), Woody Plant Medium (WPM) (Lloyd and McCown 1980; Mao et al. 2018) or Murashige and Skoog's (MS) (Murashige and Skoog 1962) modified in different ways depending on a species or cultivar (Vejsadová 2008).

Growth regulators play significant role during plant regeneration and cytokinins are especially significant for proliferation. In this work all cytokinins under study increased explant regeneration and those which increased most the propagation ratio, i.e. the new shoot number per explant, were ZEA, TDZ and combination of ZEA with 2-isopenthenyloadenine (2iP). The joint use of the two latter compounds resulted in three-fold increase in new shoot number relative to the control devoid of cytokinins ( 3 shoots per explant were obtained). According to the literature the most frequently recommended cytokinins for micropropagation of Rhododendron are TDZ and 2iP (Blazich et al. 1986; Eeckhaut et al. 2010; Zaytseva et al. 2016). For $R$. macabeanum 2iP was most suitable (Mao et al. 2017), similarly as for the cultivars such as: 'Azuro', 'Bohumil Kavka', 'Catharine van Toll', 'Grandiflorum', 'Mars', 'Nova Zembla', 'Ortrud', 'Ovation', 'Prof. Scholz', 'Purple Splendour', 'Rebe and Van Werden', 'Poelmandla' (Vejsadová 2008). In $R$. mucronulatum the synthetic cytokinin TDZ gave the best results (Novikova et al. 2020).

In this work the natural cytokinin zeatin needs an attention as it gave the same number of new shoots ( 2 per 
explant) as the synthetic one - TDZ - commonly regarded as the most active in proliferation. It also stimulated shoot growth so in the treatments with ZEA or ZEA+2iP the shoots were the longest. Such a stimulation of shoot elongation by zeatin applied together with $2 \mathrm{iP}$ was also reported for $R$. indicum (Rahimi et al. 2013). According to Rahimi et al. (Rahimi et al. 2013), the natural cytokinin 2iP acts synergistically with ZEA enhancing its action however, when used alone in micropropagation of $R$. 'Kazimierz Odnowiciel' it gave mediocre or comparable to the control results.

Undoubtedly, exogenous plant growth regulators are not the only factors affecting regeneration in vitro. Significant effects of stresses such as osmotic, mechanical or that resulting from $\mathrm{pH}$ changes in a medium have often been reported (Libik et al. 2005; Desjardins et al. 2009). A common plant response to different stress factors is overproduction of the reactive oxygen species (ROS), including the most stable one, i.e. hydrogen peroxide (Hodges et al. 2001; Osório et al. 2013). The highest $\mathrm{H}_{2} \mathrm{O}_{2}$ concentration was found in shoots from media supplemented with TDZ or $2 \mathrm{iP}+\mathrm{ZEA}$. In the case of TDZ it is a frequent plant response due to strong action of this synthetic cytokinin. At first, TDZ was used as a defoliant, the recent investigations show that its action is associated with stress and increased $\mathrm{H}_{2} \mathrm{O}_{2}$ concentration in plant cells what results in leaf abscission (Li et al. 2020). A high hydrogen concentration is harmful as it damages structural cell elements due to their oxidation and degradation what in consequence provokes death of cells and the whole organism. To avoid this plants developed a defense mechanism including antioxidative enzymes decomposing ROS, such as catalases or peroxidases.

Decrease in catalase activity occurs in many plants undergoing oxidative stress (Shim et al. 2003). In Rhododendron 'Kazimierz Odnowiciel' the lowest catalase activity - comparable to that in control plants - was recorded in microshoots regenerated on the medium containing TDZ. However, often catalase activity is increased as a part of the activated antioxidative defense system in response to unfavorable culture conditions being an adaptive plant response to abiotic stress. We may speculate that without increased catalase activity the plant growth inhibition might have been more severe (Leung 2018). In the shoots regenerated on medium with any of the cytokinins under study the hydrogen peroxide contents were elevated relative to the control and the catalase activity enhanced. In the case of the medium containing $2 \mathrm{iP}+\mathrm{ZEA}$ the reason of a high hydrogen peroxide concentration is difficult to define: it is not a defense response of microcuttings as here the proliferation was the best and morphogenesis was not disturbed. It is also worthy to note that in this treatment the lowest peroxidase activity was concomitant with the highest activity of catalase so the balance of the antioxidant system was positive.
According to numerous reports a decrease in chlorophyll content is a typical symptom of oxidative stress (Egert and Tevini 2002; Gholami et al. 2012). This was evident in shoots from the medium containing TDZ, with contents of chlorophyll and carotenoids only slightly higher than in control plants. In turn, the highest chlorophyll contents were determined in shoots regenerated in presence of $2 \mathrm{iP}+\mathrm{ZEA}$ where proliferation was the best and no symptoms of oxidative stress were evident.

Apart from antioxidative enzymes the low molecule antioxidants are included in plant defense system and carotenoids belong to this group (Şen 2012). However, a high carotenoid concentration may also be a stress symptom. In Rosmarinus officinalis growing under water deficit carotenoid concentration kept increasing providing a photoprotection against oxidative damages (Munné-Bosch and Alegre 2000). Therefore, we may speculate that in the treatment with 2iP+ZEA where proliferation was the best, the high carotenoid concentration together with antioxidative enzymes activities provided a good protection again stress conditions in vitro allowing undisturbed growth and development of regenerated shoots.

During micropropagation the photosynthesis parameters often decrease because of a lower $\mathrm{CO}_{2}$ concentration in culture containers (Kozai 1991; Van Huylenbroeck et al. 2000). Cytokinins affect functional and structural aspects of photosynthesis on several levels and act antagonistically to abscisic acid so they are able to increase stomatal conductance and thus modify gas exchange in leaves and increase availability of $\mathrm{CO}_{2}$ indispensable for photosynthesis (Stoynova et al. 1996; Kulaeva et al. 2002; Hönig et al. 2018). Such cytokinin action was confirmed in this work where the lowest chlorophyll level and content of total soluble sugars were found in shoots regenerated on control medium without cytokinins and the highest values of both parameters were in plants developed on medium with 2iP+ZEA.

As the final product of photosynthesis are carbohydrates used by plants as the energy source this process is crucial for all the aspects of plant growth and development (Lawlor 2009). Under stress conditions like for example shading common during micropropagation, considerable decreases in contents of starch, total soluble sugars and sucrose occur (Xiaotao et al. 2013). The results with chrysanthemums confirmed that cytokinins maintain a high sugar level and limit lipid peroxidation (Kaur and Singh 2015) what was also proved in this work on Rhododendron micropropagated on the medium supplemented with two cytokinins - 2iP+ZEA.

Quality of the regenerated microcuttings depends as well on genetic stability. i.e. repeatability of features decisive for cultivar originality. In micropropagation - which is a method of vegetative i.e. clonal propagation - the multiplied material should be phenotypically and genetically identical with mother plant. However, as reported 
by many authors this is not always true (Saeiahagh et al. 2019; Samarina et al. 2019; Novikova et al. 2020; Nowakowska and Pacholczak 2020). To evaluate the effects of cytokinins on genetic stability during micropropagation of Rhododendron it has been checked already after the first phase, i.e. proliferation. Reduced cytokinin status results in increased photooxidative stress, and plants then show reduced ROS scavenging capacity and have higher levels of photodamage (Cortleven et al. 2014). Cytokinins play an important role not only during processes related to cell division and, consequently proliferation, but they also play a key role in response to abiotic stresses, such as drought, high or low temperature. One might even be tempted to formulate that cytokinins are central regulators of plant development and stress responses ( $\mathrm{Li}$ et al. 2021). Therefore, we suspect that this is the reason for such a marked variability that appeared between plants regenerating on medium without cytokinins $(0)$ and the mother plant. The difference between control (0) and combinations with natural cytokinins was also observed. The highest variability was found for synthetic cytokinins (BA and TDZ) and is $16 \%$ compared to the other combinations. Looking at the whole study it is possible to eliminate these cytokinins from further in vitro propagation of Rhododendron 'Kazimierz Odnowiciel'. Such an early intervention seems important as it allows to remove the regenerants genetically different from stock plant already during the early phase of propagation thus saving time and costs on propagation of material not repeating the desired traits of a cultivar. ISSR markers are useful for evaluation of somaclonal variability (Saha et al. 2016; Nowakowska and Pacholczak 2020). In $R$. 'Kazimierz Odnowiciel' the obtained microcuttings varied in a low percent. Also in micropropagated $R$. mucronulatum a low polymorphism was found (about $1 \%$ ) but the evaluation was performed with only 8 ISSR markers (Novikova et al. 2020). For microcuttings of Rhododendron wattii no polymorphism was detected but less markers were used than in this work (Mao et al. 2018). Such low frequency of changes - below $10 \%$ of existing polymorphism - allows to positively evaluate micropropagation as a propagation method and to assume that the obtained microcuttings will be phenotypically identical with stock material.

\footnotetext{
Authors contribution Karolina Nowakowska: conceptualization, methodology, biochemical and molecular analysis, analysis and interpretation of date and writing — original draft preparation; Anna Pińkowska: molecular analysis, analysis and interpretation of date, visualization; Ewa Siedlecka: molecular biology consultations, assistance in interpreting molecular results, supervision; Andrzej Pacholczak: formal analysis, analysis and interpretation of date, writing-original draft preparation, visualization; supervision; All authors have read and agreed to the published version of the manuscript.
}

Funding This research received no external funding.

Data availability Data sharing not applicable to this article as no datasets were generated or analysed during the current study

\section{Declarations}

Conflict of interest The authors have no conflicts of interest to declare that are relevant to the content of this article.

Open Access This article is licensed under a Creative Commons Attribution 4.0 International License, which permits use, sharing, adaptation, distribution and reproduction in any medium or format, as long as you give appropriate credit to the original author(s) and the source, provide a link to the Creative Commons licence, and indicate if changes were made. The images or other third party material in this article are included in the article's Creative Commons licence, unless indicated otherwise in a credit line to the material. If material is not included in the article's Creative Commons licence and your intended use is not permitted by statutory regulation or exceeds the permitted use, you will need to obtain permission directly from the copyright holder. To view a copy of this licence, visit http://creativecommons.org/licenses/by/4.0/.

\section{References}

Amin S, Wani TA, Kaloo ZA et al (2018) Genetic stability using RAPD and ISSR markers in efficiently in vitro regenerated plants of Inula royleana DC. Meta Gene 18:100-106. https://doi.org/10.1016/j. mgene.2018.08.006

Anderson WC (1984) A revised tissue culture medium for shoot multiplication of rhododendron. J Am Soc Hortic Sci 109:343-347

Bhattacharyya P, Kumar V, Van Staden J (2017) Assessment of genetic stability amongst micropropagated Ansellia africana, a vulnerable medicinal orchid species of Africa using SCoT markers. South African J Bot 108:294-302. https://doi.org/10.1016/j.sajb.2016. 11.007

Bian S, Jiang Y (2009) Reactive oxygen species, antioxidant enzyme activities and gene expression patterns in leaves and roots of Kentucky bluegrass in response to drought stress and recovery. Sci Hortic (Amsterdam) 120:264-270. https://doi.org/10.1016/j.scien ta.2008.10.014

Blazich FA, Giles CG, Haemmerle CM (1986) Micropropagation of Rhododendron chapmanii. J Environ Hortic 4:26-29. https://doi. org/10.24266/0738-2898-4.1.26

Compton ME (1994) Statistical methods suitable for the analysis of plant tissue culture data. Plant Cell Tissue Organ Cult 37:217-242.

Cortleven A, Nitschke S, Klaumünzer M et al (2014) A novel protective function for cytokinin in the light stress response is mediated by the Arabidopsis Histidine Kinase2 and Arabidopsis Histidine Kinase3 receptors. Plant Physiol 164:1470-1483. https://doi.org/ 10.1104/pp.113.224667

Czekalski M (1983) Różaneczniki, I. Państwowe Wydawnictwo Rolnicze i Leśne, Warszawa

Desjardins Y, Dubuc JF, Badr A (2009) In vitro culture of plants: A stressful activity! Acta Hortic 812:29-50. https://doi.org/10. 17660/ActaHortic.2009.812.1

Dubois M, Gilles KA, Hamilton JK et al (1956) Colorimetric method for determination of sugars and related substances. Anal Chem 28:350-356. https://doi.org/10.1021/ac60111a017

Eeckhaut T, Janssens K, De Keyser E, De Riek J (2010) Micropropagation of Rhododendron. In: In: Jain SM, Ochatt, Sergio J (eds) 
Protocols for In Vitro Propagation of Ornamental Plants. Methods in Molecular Biology. Humana Press, pp 141-152

Egert M, Tevini M (2002) Influence of drought on some physiological parameters symptomatic for oxidative stress in leaves of chives (Allium schoenoprasum). Environ Exp Bot 48:43-49. https://doi. org/10.1016/S0098-8472(02)00008-4

Gaspar T, Keveks C, Penel C et al (1996) Plant hormones and plant growth regulators in plant tissue culture. Vitr Cell Dev Biol - Plant 32:272-289. https://doi.org/10.1007/BF02822700

Gholami M, Rahemi M, Kholdebarin B, Rastegar S (2012) Biochemical responses in leaves of four fig cultivars subjected to water stress and recovery. Sci Hortic (Amsterdam) 148:109-117. https:// doi.org/10.1016/j.scienta.2012.09.005

Góth L (1991) A simple method for determination of serum catalase activity and revision of reference range. Clin Chim Acta 196:143-151. https://doi.org/10.1016/0009-8981(91)90067-M

Hallmark HT, Rashotte AM (2019) Review-Cytokinin response factors: responding to more than cytokinin. Plant Sci 289:110251. https://doi.org/10.1016/j.plantsci.2019.110251

Hodges DM, Forney CF, Wismer Wendy V (2001) Antioxidant responses in harvested leaves of two cultivars of spinach differing in senescence rates. Am Soc Hortic Sci 126:611-617

Hönig M, Plíhalová L, Husičková A et al (2018) Role of cytokinins in senescence, antioxidant defence and photosynthesis. Int J Mol Sci 19:4045. https://doi.org/10.3390/ijms19124045

Hussain A, Ahmed I, Nazir H, Ullah I (2012) Plant tissue culture: current status and opportunities. In: In: Leva A, Rinaldi LMR (eds) Recent advances in plant in vitro culture. InTech, Rijeka, pp 1-28

Jaccard P (1908) Nouvelles recherches sur la distribution florale. Bull Soc Vaud Sci Nat 44:223-270

Jílek A (2012) Odolné polské odrůdy rododendronů. Školkařství 10:42-43

Kaur P, Singh K (2015) Influence of Growth regulators on Physiology and Senescence of Cut Stems of Chrysanthemum (Chrysanthemum morifolium Ramat) Var. Thai Ching Queen. IJAPRR Int Peer Rev Ref J 2:31-41

Kozai T (1991) Photoautotrophic micropropagation. Vitr Cell Dev Biol - Plant 27P:47-51

Kulaeva ON, Burkhanova EA, Karavaiko NN et al (2002) Chloroplasts affect the leaf response to cytokinin. J Plant Physiol 159:13091316. https://doi.org/10.1078/0176-1617-00761

Larkin PJ, Scowcroft WR (1981) Somaclonal variation - a novel source of variability from cell cultures for plant improvement. Theor Appl Genet 60:197-214. https://doi.org/10.1007/BF023 42540

Lawlor DW (2009) Musings about the effects of environment on photosynthesis. Ann Bot 103:543-549. https://doi.org/10.1093/aob/ $\operatorname{mcn} 256$

Leung DWM (2018) Studies of catalase in plants under abiotic stress. In: In: Gupta DK, Palma JM, Corpas FJ (eds) Antioxidants and Antioxidant Enzymes in Higher Plants. Springer, Cham, pp 27-39

Li S, Liu R, Wang X et al (2020) Involvement of hydrogen peroxide in cotton leaf abscission induced by thidiazuron. J Plant Growth Regul. https://doi.org/10.1007/s00344-020-10218-w

Li SM, Zheng HX, Zhang XS, Sui N (2021) Cytokinins as central regulators during plant growth and stress response. Plant Cell Rep 40:271-282. https://doi.org/10.1007/s00299-020-02612-1

Libik M, Konieczny R, Pater B et al (2005) Differences in the activities of some antioxidant enzymes and in $\mathrm{H} 2 \mathrm{O} 2$ content during rhizogenesis and somatic embryogenesis in callus cultures of the ice plant. Plant Cell Rep 23:834-841. https://doi.org/10.1007/ s00299-004-0886-8

Lichtenthaler HK, Wellburn AR (1983) Determinations of total carotenoids and chlorophylls a and $\mathrm{b}$ of leaf extracts in different solvents. Biochem Soc Trans 11:591-592. https://doi.org/10.1042/ bst0110591

Lloyd G, McCown B (1980) Commercially-feasible micropropagation of mountain laurel Kalmia latifolia by use of shoot-tip culture. Comb Proceedings, Int Plant Propagators' Soc 30:421-427

Mao AA, Vijayan D, Nilasana Singha RK, Pradhan S (2018) In vitro propagation of Rhododendron wattii Cowan-a critically endangered and endemic plant from India. Vitr Cell Dev Biol - Plant 54:45-53. https://doi.org/10.1007/s11627-017-9869-7

Mao J, Zhang D, Li K et al (2017) Effect of exogenous Brassinolide (BR) application on the morphology, hormone status, and gene expression of developing lateral roots in Malus hupehensis. Plant Growth Regul 82:391-401. https://doi.org/10.1007/ s10725-017-0264-5

Munné-Bosch S, Alegre L (2000) Changes in carotenoids, tocopherols and diterpenes during drought and recovery, and the biological significance of chlorophyll loss in Rosmarinus officinalis plants. Planta 210:925-931. https://doi.org/10.1007/s004250050699

Murashige T, Skoog F (1962) A revised medium for rapid growth and bio assays with tobacco tissue cultures. Physiol Plant 15:473-497. https://doi.org/10.1111/j.1399-3054.1962.tb08052.x

Novikova TI, Asbaganov SV, Ambros EV, Zaytseva YG (2020) TDZinduced axillary shoot proliferation of Rhododendron mucronulatum Turcz and assessment of clonal fidelity using DNA-based markers and flow cytometry. Vitr Cell Dev Biol - Plant 56:307317. https://doi.org/10.1007/s11627-019-10049-9

Nowakowska K, Pacholczak A (2020) Comparison of the effect of meta-Topolin and benzyladenine during Daphne mezereum L. micropropagation. Agronomy 10:1994. https://doi.org/10.3390/ agronomy10121994

Nowakowska K, Pacholczak A, Tepper W (2019) The effect of selected growth regulators and culture media on regeneration of Daphne mezereum L. 'Alba' Rend Lincei 30:197-205. https://doi.org/10. 1007/s12210-019-00777-w

Osório ML, Gonçalves S, Coelho N et al (2013) Morphological, physiological and oxidative stress markers during acclimatization and field transfer of micropropagated Tuberaria major plants. Plant Cell Tissue Organ Cult 115:85-97. https://doi.org/10.1007/ s11240-013-0343-x

Pacholczak A, Nowakowska K (2019) Micropropagation of february daphne (Daphne mezereum L.). Propag Ornam Plants 19:106-112

Pick E, Keisari Y (1980) A simple colorimetric method for the measurement of hydrogen peroxide produced by cells in culture. J Immunol Methods 38:161-170. https://doi.org/10.1016/00221759(80)90340-3

Pierik RLM (1990) Rejuvenation and Micropropagation. In: In: Nijkamp HJJ, Van Der Plas LHW, Van Aartrijk J (eds) Progress in Plant Cellular and Molecular Biology. Kluwer Academic Publishers, Dordrecht, pp 91-101

Podwyszynska M, Gabryszewska E, Korbin M, Jasinski A (2010) Evaluation of somaclonal variation in micropropagated Hemerocallis sp plants using phenotype and ISSR markers. Biotechnologia $2: 114-124$

Rademacher W (2015) Plant growth regulators: backgrounds and uses in plant production. J Plant Growth Regul 34:845-872. https://doi. org/10.1007/s00344-015-9541-6

Rahimi S, Naderi R, Ghaemaghami SA et al (2013) Study on effects of different plant growth regulators types in shoot regeneration and node formation of Sutsuki Azalea (Rhododendron indicum): a commercially important Bonsai. Procedia Eng 59:240-246. https://doi.org/10.1016/j.proeng.2013.05.117

Rathore JS, Rathore V, Shekhawat NS et al (2005) Micropropagation of Woody Plants. In: In: Srivastava PS, Narula A, Srivastava S (eds) Plant Biotechnology and Molecular Markers. Anamaya Publishers, New Delhi, pp 195-205 
Rodríguez JL, Pascual J, Viejo M et al (2012) Basic Procedures for Epigenetic Analysis in Plant Cell and Tissue Culture. In: In: Clifton NJ (ed) Methods in Molecular Biology. Humana Press, Totowa, NJ, pp 325-341

Rout GR, Mohapatra A, Jain SM (2006) Tissue culture of ornamental pot plant: A critical review on present scenario and future prospects. Biotechnol Adv 24:531-560. https://doi.org/10.1016/j.biote chadv.2006.05.001

Saeiahagh H, Mousavi M, Wiedow C et al (2019) Effect of cytokinins and sucrose concentration on the efficiency of micropropagation of 'Zes006' Actinidia chinensis var. chinensis, a red-fleshed kiwifruit cultivar. Plant Cell, Tissue Organ Cult 138:1-10. https://doi. org/10.1007/s11240-019-01597-4

Saha S, Adhikari S, Dey T, Ghosh P (2016) RAPD and ISSR based evaluation of genetic stability of micropropagated plantlets of Morus alba L. variety S-1. Meta Gene 7:7-15. https://doi.org/10. 1016/j.mgene.2015.10.004

Samarina L, Gvasaliya M, Koninskaya N et al (2019) A comparison of genetic stability in tea [Camellia sinensis (L.) Kuntze] plantlets derived from callus with plantlets from long-term in vitro propagation. Plant Cell, Tissue Organ Cult 138:467-474. https://doi. org/10.1007/s11240-019-01642-2

Santner A, Calderon-Villalobos LIA, Estelle M (2009) Plant hormones are versatile chemical regulators of plant growth. Nat Chem Biol 5:301-307. https://doi.org/10.1038/nchembio.165

Şen A (2012) Oxidative Stress Studies in Plant Tissue Culture. In: ElMissiry MA (ed) Antioxidant Enzyme. InTech, pp 59-88. https:// doi.org/10.5772/48292

Shim IS, Momose Y, Yamamoto A et al (2003) Inhibition of catalase activity by oxidative stress and its relationship to salicylic acid accumulation in plants. Plant Growth Regul 39:285-292. https:// doi.org/10.1023/A:1022861312375

de Souza LM, Silva MM, de Herculano A et al (2019) Meta-topolin: an alternative for the prevention of oxidative stress in sugarcane micropropagation. Hoehnea 46:0-4. https://doi.org/10.1590/22368906-107/2018
Stoynova EZ, Iliev LK, Georgiev GT (1996) Structural and functional alterations in radish plants induced by the phenylurea cytokinin 4-PU-30. Biol Plant 38:237-244. https://doi.org/10.1007/BF028 73852

Toczko M, Grzelińska A (2001) Materiały do ćwiczeń z biochemii [Materials for biochemistry exercises]. SGGW, Warszawa

Van Huylenbroeck JM, Piqueras A, Debergh PC (2000) The evolution of photosynthetic capacity and the antioxidant enzymatic system during acclimatization of micropropagated Calathea plants. Plant Sci 155:59-66. https://doi.org/10.1016/S0168-9452(00)00201-6

Vejsadová H (2008) Growth regulator effect on in vitro regeneration of rhododendron cultivars. Hortic Sci 35:90-94. https://doi.org/ 10.17221/643-HORTSCI

Wójcik AR, Laudański Z (1989) Planowanie i wnioskowanie statystyczne w doświadczalnictwie [Statistical planning and concluding in experimental works]. Państwowe Wydawnictwo Naukowe, Warszawa

Xiaotao D, Yuping J, Hong W et al (2013) Effects of cytokinin on photosynthetic gas exchange, chlorophyll fluorescence parameters, antioxidative system and carbohydrate accumulation in cucumber (Cucumis sativus L.) under low light. Acta Physiol Plant 35:14271438. https://doi.org/10.1007/s11738-012-1182-9

Zaytseva YG, Poluboyarova TV, Novikova TI (2016) Effects of thidiazuron on in vitro morphogenic response of Rhododendron sichotense Pojark. and Rhododendron catawbiense cv. Grandiflorum leaf explants. Vitr Cell Dev Biol - Plant 52:56-63. https://doi.org/ 10.1007/s11627-015-9737-2

Publisher's Note Springer Nature remains neutral with regard to jurisdictional claims in published maps and institutional affiliations. 